\title{
Improving the quality of ground mutton by garlic oil
}

\author{
Marwa M. Emam ${ }^{1 *}$, Samir M. Abd-Elghany ${ }^{1}$, Hazem H. Ramadan², Mahmoud A. Mahros ${ }^{1}$
}

${ }^{1}$ Food Hygiene and Control Department, Faculty of Veterinary Medicine, Mansoura University, Mansoura 35516, Egypt.

${ }^{2}$ Hygiene and Zoonoses Department, Faculty of Veterinary Medicine, Mansoura University, Mansoura 35516, Egypt.

\section{ARTICLE HISTORY}

Received: 06.03.2021

Revised: 10.05 .2021

Accepted: 14.06.2021

Correspondence to Marwa M. Emam; Email: marwameaah@gmail.com

\section{ABSTRACT}

\begin{abstract}
Objective: The aim of this study is to examine the antimicrobial activity of garlic oil to extend the shelf life of ground mutton stored aerobically at $4{ }^{\circ} \mathrm{C}$ for 15 days through its effect on the aerobic plate count and Enterobacteriaceae count that contaminate the meat during its preparation. Design: Observational controlled study.

Samples: $7200 \mathrm{~g}$ of fresh mutton

Procedures: meat samples were divided into four equal groups (600 gm each), three, groups were treated with different concentrations of garlic oil $(250,360$, and $600 \mathrm{mg} / \mathrm{kg}$ ) and the last group (without any addition) as a control. The treated samples were thoroughly mixed with garlic oil by hand (with sterile gloves), then the meat of each group was packaged separately in sterile polyethylene bags, marked, and stored aerobically in the refrigerator at $4{ }^{\circ} \mathrm{C}$ for 15 days and subjected to microbiological analyses and sensory evaluation.

Results: there was a significant decrease in aerobic plate count and Enterobacteriaceae count of treated meat samples in comparison with the untreated samples. Additionally, the use of garlic oil at concentration of $600 \mathrm{mg} / \mathrm{kg}$ meat has higher effect than $250 \mathrm{mg} / \mathrm{kg}$ and $360 \mathrm{mg} / \mathrm{kg}$ during the period of storage. Furthermore, garlic oil also enhanced the sensory characteristics of treated the ground mutton.

Conclusion and clinical relevance: we suggest that the addition of garlic oil to fresh mutton during cold storage is potentially useful in improving its quality and extending its shelf-life.
\end{abstract}

Keywords: Mutton; Garlic oil; Shelf life; Sensory attributes.

\section{INTRODUCTION}

Mutton is considered an exceptional source of wellbalanced essential amino acids, good quality animal proteins with high biological value and valuable nutrients such as minerals, vitamins particularly B complex, iron, selenium, zinc and, beneficial fatty acids such as $\alpha$-linolenic and conjugated linoleic acids [1]. It is the richest meat source of conjugated linoleic acid (CLA) which has anticarcinogenic, antiatherogenic and antidiabetic activities as well as other health benefits. Additionally, mutton is also relatively high in phosphatidylcholine derivatives, which are suggested to prevent most cardiovascular disease $[2,3]$.

Meat is nutrient-dense food that provides favorable condition for the growth of most bacteria. The meat itself is sterile within the animal's body. However, it can easily become contaminated during slaughter, abattoir practice, handling during processing, mincing machine, storage, and distribution [4]. In fresh meat and meat products microorganisms multiply rapidly, especially at nonrefrigeration temperature. Hence, for prevention of such microbial growth and multiplication various methods of processing and preservation are required to inactivate or inhibit growth of microbes [5]. The addition of compounds derived from natural sources such as essential oils derived from plants (e.g., garlic, thyme, basil, and sage) to the food to be preserved is potentially useful to extend shelf life and improve quality of the product [6].

Garlic (Allium sativum) is a bulbous herb belongs to genus allium which is cultivated and used as food item and medicine in different parts of the world. Garlic has been suggested to be used as bio preservative of food due to the antibacterial action of its extract and essential oil. It has prophylactic and therapeutic actions due to its antimicrobial, antineoplastic, antioxidant, and immune boosting in addition to its antidiabetic and hepatoprotective properties [7 \& 8].

There are many studies have been carried out on mutton but there are no previous studies have been published on the preservation and shelf-life extension of this kind of meat by addition of garlic oil. Therefore, the objective of this study is to examine the antimicrobial activity of garlic oil at various concentrations on the shelf life of mutton during the cold storage at $4{ }^{\circ} \mathrm{C}$ through its effect on spoilage bacteria that contaminate the meat during its preparation.

\section{MATERIALS AND METHODS}

\subsection{Collection of samples}

A total of $2400 \mathrm{~g}$ of fresh mutton was purchased from a local butchers' shop in Mansoura city, Egypt. Meat samples were aseptically packed into a polyethylene bag cooled, in icebox, and transferred directly to the laboratory of Food Hygiene and Control department, Faculty of Veterinary Medicine, Mansoura University, without undue delay, wherein the bacteriological examinations and sensory evaluation were done. In the laboratory, meat samples were ground. Garlic oil (valid for consumption) was purchased from a local market in Mansoura city, Egypt. Garlic oil was added to the surface of ground meat and distributed by hands (with sterile gloves). Then, meat samples were packed 
individually, in polyethylene bags and kept in refrigeration storage at $4{ }^{\circ} \mathrm{C}$, and examined in the $0,3,6,9,12$, and 15 , days of storage.

\subsection{Bacteriological analyses}

Ten grams from each meat sample were aseptically transferred to a laboratory blender flask (Moulinex, France) to be homogenized, for one minute, with $90 \mathrm{ml}$ of $0.1 \%$ sterile peptone water (Oxoid CM0009) for obtaining an original dilution of 1:10. Then, tenfold serial dilutions were made by transferring one $\mathrm{ml}$ from each of the original dilution aseptically to sterile test tubes containing $9 \mathrm{ml}$ of sterile peptone water to be diluted in a sequential manner up to $10^{-6}$ to cover the expected range of contamination with aerobic bacteria and Enterobacteriaceae.

\subsubsection{Determination of aerobic plate counts (APCS) [9].}

A tenth $\mathrm{ml}$ from each prepared serial dilution was aseptically transferred and evenly spread over a dry surface of previously prepared sterile plate count agar (Oxoid CM0325). The inoculated plates surface was left to dry for 15 min before being placed inverted with control plates in the incubator at $30{ }^{\circ} \mathrm{C}$ for $24-48 \mathrm{~h}$. The bacterial colonies in the countable plates (having 30-300 colonies) were counted and APCs per each $g$ of the examined samples were then calculated and recorded.

\subsubsection{Enterobacteriaceae counts (ECS) [10].}

One $\mathrm{ml}$ amounts of the chosen range of prepared dilutions were transferred and inoculated into duplicated sets of sterile Petri dishes, then about $15 \mathrm{ml}$ of violet red bile glucose agar (Oxoid CM0485) melted and allowed to cool to $45^{\circ} \mathrm{C}$ was poured to each inoculated Petri dish, then mixed well and allowed to solidify. Additional thin layer of the same agar was poured above the previous solidified medium and plates were left to solidify, then finally incubated "inverted" at $30{ }^{\circ} \mathrm{C}$ for $24 \mathrm{~h}$. Enumeration of typical colonies (red surrounded by precipitation of bile salts in the medium and having $0.5 \mathrm{~mm}$ or more in diameter) of Enterobacteriaceae was done and ECs per each $g$ of the examined sample was calculated and recorded.

\section{3. Sensory evaluation}

Sensory evaluation for the control and treated meat samples was carried out on the following day of meat preparation. Representative sample from each group were taken and made into meatballs then placed separately in a clean aluminum foil plate. The plates were blind-coded and adequately cooked in an electrical cooking oven at $180{ }^{\circ} \mathrm{C}$ for $20 \mathrm{~min}$ then introduced to 10 panelists from staff members of Food Hygiene and Control Department to determine the intensity of garlic flavor, tenderness and overall acceptability scores of the ground meat [11]. Panelists were asked to rinse their mouth between each sample.

\section{4. Statistical analysis}

Meat samples were analyzed on the $0,3^{\text {rd }}, 6^{\text {th }}, 9^{\text {th }}, 12^{\text {th }}$, and $15^{\text {th }}$ days of cold storage and all measurements were carried out in triplicate, then data obtained in this study were collected, arranged, summarized, and then statistically analyzed using analysis of variance (ANOVA). Significance was defined at $\mathrm{P}<0.01$.

\section{RESULTS AND DISCUSSION}

\subsection{Effect of addition of garlic oil at different concentrations on aerobic plate counts}

The shelf life of meat and meat products depends mainly on the intensity of microbial contaminants that multiply rapidly in meat causing food spoilage. For preventing such microbial multiplication various methods of preservation are required to inhibit microbial growth to ensure public health protection and longer shelf lives. APCs estimates the total number of viable aerobic bacteria per gram or milliliter of meat. It is the most important information applied to estimate the quality, spoilage and safety of meat and other food [12]. In this study, the values of APCs ( $\log _{10} \mathrm{CFU} / \mathrm{g}$ ) ranged from 4.66 at zero day to 8.34 at $15^{\text {th }}$ day in mutton treated with garlic oil at concentration of $250 \mathrm{mg} / \mathrm{kg}$ indicating significant $(P<0.01)$ decrease on APCs, from $4.43 \log _{10}$ CFU/g at zero day to $7.82 \log _{10}$ CFU/g at $15^{\text {th }}$ day in mutton meat treated with garlic oil at concentration of $360 \mathrm{mg} / \mathrm{kg}$ and from 4.3 at zero day to 7.21 at $15^{\text {th }}$ day in mutton meat treated with garlic oil at concentration of 600 $\mathrm{mg} / \mathrm{kg}$. Our findings indicated that garlic oil at different concentrations produced a significant reduction in APCs when compared with control samples that ranged from 4.98 $\log _{10} \mathrm{CFU} / \mathrm{g}$ at zero-day to8.95 $\log _{10} \mathrm{CFU} / \mathrm{g}$ at $15^{\text {th }}$ (Table 1 ).

Table 1. The effect of addition of garlic oil at different concentrations on aerobic plate counts.

\begin{tabular}{lllll|}
$\begin{array}{l}\text { Day of } \\
\text { storage }\end{array}$ & \multicolumn{4}{l}{ Garlic concentrations } \\
& Control & $\begin{array}{l}250 \\
\mathrm{mg} / \mathrm{kg}\end{array}$ & $\begin{array}{l}360 \\
\mathrm{mg} / \mathrm{kg}\end{array}$ & $600 \mathrm{mg} / \mathrm{kg}$ \\
0 & $4.98^{\mathrm{a}}$ & $4.66^{\mathrm{b}}$ & $4.43^{\mathrm{bc}}$ & $4.3^{\mathrm{c}}$ \\
3 & $6.01^{\mathrm{a}}$ & $5.89^{\mathrm{ab}}$ & $5.44^{\mathrm{b}}$ & $5.03^{\mathrm{c}}$ \\
6 & $6.87^{\mathrm{a}}$ & $6.22^{\mathrm{ab}}$ & $5.83^{\mathrm{b}}$ & $5.42^{\mathrm{c}}$ \\
9 & $7.12^{\mathrm{a}}$ & $6.92^{\mathrm{b}}$ & $6.53^{\mathrm{bc}}$ & $6.14^{\mathrm{c}}$ \\
12 & $8.3^{\mathrm{a}}$ & $7.43^{\mathrm{b}}$ & $7.17^{\mathrm{bc}}$ & $6.87^{\mathrm{c}}$ \\
15 & $8.95^{\mathrm{a}}$ & $8.34^{\mathrm{ab}}$ & $7.82^{\mathrm{ab}}$ & $7.21^{\mathrm{b}}$
\end{tabular}

$\mathrm{a}-\mathrm{C}=$ Means with different letters in the same row are significantly different at $\mathrm{P}<0.01$.

Similar findings were mentioned by Yin and Cheng [12] who reported that the addition of organosulfur compounds derived from garlic to ground beef results in a significant reduction in APCs. Additionally, a study performed in Egypt revealed that garlic oil at $1.5 \%$ produced a major reduction of APCs in treated minced beef samples and exhibited longer shelf life than the control samples by 6 days [13].

\subsection{Effect of addition of garlic oil at different concentrations on Enterobacteriaceae}


Enterobacteriaceae are the most important indicators used to assess the bad hygiene or bad treatment of food. The presence of Enterobacteriaceae in a large number may be an indication of their multiplication and implying multiplication of other pathogens. In the present study, the values of ECs $\left(\log _{10} \mathrm{CFU} / \mathrm{g}\right)$ ranged from 3.58 at zero day to 6.31 at $15^{\text {th }}$ day in mutton meat treated with garlic oil at concentration of $250 \mathrm{mg} / \mathrm{kg}$, from $3.48 \log _{10} \mathrm{CFU} / \mathrm{g}$ at zero day to $5.84 \log _{10} \mathrm{CFU} / \mathrm{g}$ at $15^{\text {th }}$ day in mutton meat treated with garlic oil at concentration of $360 \mathrm{mg} / \mathrm{kg}$ and from 3.35 at zero day to 5.07 at $15^{\text {th }}$ day in mutton meat treated with garlic oil at concentration of $600 \mathrm{mg} / \mathrm{kg}$.while ECs in control samples ranged from $3.55 \log _{10} \mathrm{CFU} / \mathrm{g}$ at zero day to 6.83 $\log _{10} \mathrm{CFU} / \mathrm{g}$ at $15^{\text {th }}$ which indicated that garlic oil delayed the growth of Enterobacteriaceae and showed inhibition in ECs by the time (Table 2). It is obvious from our results that the increase in garlic oil concentration produces an increase in its antibacterial effect.

Table 2. The effect of addition of garlic oil at different concentrations on Enterobacteriaceae counts.

\begin{tabular}{lllll}
$\begin{array}{l}\text { Day } \\
\text { storage }\end{array}$ & of & \multicolumn{4}{c}{$\begin{array}{l}\text { Garlic concentrations } \\
\text { Control }\end{array}$} & $\begin{array}{l}250 \\
\mathrm{mg} / \mathrm{kg}\end{array}$ & $\begin{array}{l}360 \\
\mathrm{mg} / \mathrm{kg}\end{array}$ & $600 \mathrm{mg} / \mathrm{kg}$ \\
$\mathbf{0}$ & $3.55^{\mathrm{a}}$ & $3.58^{\mathrm{a}}$ & $3.48^{\mathrm{a}}$ & $3.35^{\mathrm{a}}$ \\
$\mathbf{3}$ & $4.38^{\mathrm{a}}$ & $4.22^{\mathrm{a}}$ & $3.93^{\mathrm{a}}$ & $3.65^{\mathrm{a}}$ \\
$\mathbf{6}$ & $4.89^{\mathrm{a}}$ & $4.63^{\mathrm{a}}$ & $4.45^{\mathrm{a}}$ & $4.32^{\mathrm{a}}$ \\
$\mathbf{9}$ & $5.53^{\mathrm{a}}$ & $5.32^{\mathrm{ab}}$ & $5.13^{\mathrm{ab}}$ & $4.65^{\mathrm{b}}$ \\
$\mathbf{1 2}$ & $6.32^{\mathrm{a}}$ & $6.02^{\mathrm{ab}}$ & $5.54^{\mathrm{bc}}$ & $4.78^{\mathrm{c}}$ \\
$\mathbf{1 5}$ & $6.83^{\mathrm{a}}$ & $6.31^{\mathrm{ab}}$ & $5.84^{\mathrm{bc}}$ & $5.07^{\mathrm{c}}$
\end{tabular}

a-c=Means with different letters in the same row are significantly different at $P<0.01$

Table 3. The effect of addition of garlic oil at different concentrations on sensory attributes of mutton meatballs.

\begin{tabular}{|c|c|c|c|c|}
\hline \multirow{2}{*}{$\begin{array}{l}\text { Sensory } \\
\text { attributes }\end{array}$} & \multicolumn{4}{|c|}{ Garlic concentrations } \\
\hline & Control & $\begin{array}{l}250 \\
\mathrm{mg} / \mathrm{kg}\end{array}$ & $\begin{array}{l}360 \\
\mathrm{mg} / \mathrm{kg}\end{array}$ & $\begin{array}{l}600 \\
\mathrm{mg} / \mathrm{kg}\end{array}$ \\
\hline Garlic flavor & $4.40^{a}$ & $4.93^{b}$ & $5.11^{b c}$ & $5.32^{c}$ \\
\hline Tenderness & $6.37^{a}$ & $6.94^{a}$ & $6.52^{\mathrm{a}}$ & $6.43^{\mathrm{a}}$ \\
\hline Juiciness & $6.28^{a}$ & $6.47^{a}$ & $6.34^{\mathrm{a}}$ & $6.58^{a}$ \\
\hline $\begin{array}{l}\text { Overall } \\
\text { acceptability }\end{array}$ & $7.54^{\mathrm{a}}$ & $7.69^{\mathrm{a}}$ & $7.43^{a}$ & $7.21^{\mathrm{a}}$ \\
\hline
\end{tabular}

$a-c=$ Means with different letters in the same row are significantly different at $\mathrm{P}<0.01$.

\subsection{Effect of addition of garlic oil at different concentrations on sensory attributes of mutton meatballs}

The intensity of garlic oil flavor, tenderness juiciness and overall acceptability of untreated and treated mutton meat balls are shown in Table (3). By sensory evaluation of examined mutton meat, it is shown that the treated samples had slightly bland flavor of garlic oil. There is no significant difference in the tenderness and juiciness between treated samples as all treated samples were more tender and juicier than control one. No significant difference was also detected in the overall acceptability of the tested samples. Nearly similar findings about the effect of garlic oil on the shelf life of minced camel meat storing at $4{ }^{\circ} \mathrm{C}$, were reported by many researchers worldwide and concluded that the addition of garlic oil extensively extended the shelf life and improved the sensory quality of meat [14-18].

\section{CONCLUSION}

This study concluded that the treatment of mutton with garlic oil at different concentration has a great effect in reducing aerobic plate counts and Enterobacteriaceae counts by observable levels resulted in extension of the shelf life of cold stored mutton. Additionally, garlic oil enhanced the sensory properties of treated meat. Therefore, it is recommended that the addition of garlic oil to ground mutton, as a natural additive, could improve its quality and extend the shelf life.

\section{Conflict of interest statement}

No conflict of interest.

\section{Research Ethics Committee Permission}

The current research work is permitted to be executed according to standards of Research Ethics committee, Faculty of Veterinary Medicine, Mansoura University.

\section{Authors' contribution}

Marwa M. Emam collected samples, carried out the practical part and writing the manuscript. Samir M. AbdElghany designed the experiment, shared in writing, and revised the manuscript. Hazem $H$. Ramadan supervisor Mahmoud A. Mahros supervised the practical part and revised the manuscript. All authors approved the final version of the manuscript for publication.

\section{REFERENCES}

[1] Corazzin M, Del Bianco S, Bovolenta S, Piasentier E. Carcass Characteristics and Meat Quality of Sheep and Goat. More than Beef, Pork and Chicken - The Production, Processing, and Quality Traits of Other Sources of Meat for Human Diet: Springer Int Publish 2019;11965. https://doi.org/10.1007/978-3-030-05484-7_6

[2] Mulvihill B. Ruminant meat as a source of conjugated linoleic acid (CLA). Nutrition Bull 2001;26:295-9. https://doi.org/10.1046/j.14673010.2001.00179.x

[3] Poutzalis S, Lordan R, Nasopoulou C, Zabetakis I. Phospholipids of goat and sheep origin: Structural and functional studies. Small Rumin Res 2018;167:39-47. https://doi.org/10.1016/j.smallrumres.2018.07.015

[4] Koutsoumanis K, Sofos JN. Microbial Contamination. Encyclopedia of Meat Sciences: Elsevier 2004;727-37. https://doi.org/10.1016/B0-12464970-X/00070-2

[5] Sofos JN. Microbial growth and its control in meat, poultry and fish. Quality Attributes and their Measurement in Meat, Poultry and Fish Products: Springer US 1994;359-403. https://doi.org/10.1007/978-14615-2167-9_14

[6] Ribeiro-Santos R, Andrade M, de Melo NR, Sanches-Silva A. Use of essential oils in active food packaging: Recent advances and future trends. Trends food Sci Technol 2017;61:132-40. https://doi.org/10.1016/j.tifs.2016.11.021

[7] Sharifi-Rad J, Mnayer D, Tabanelli G, Stojanović-Radić Z, Sharifi-Rad M, Yousaf Z, et al. Plants of the genus Allium as antibacterial agents: From tradition to pharmacy. Cell Molecul Biol 2016;62:57-68. https://doi.org/10.20944/preprints201711.0102.v1

[8] Tsai C-W, Chen H-W, Sheen L-Y, Lii C-K. Garlic: Health benefits and $\begin{array}{ll}\text { actions. } & \text { BioMed 2012;2:17-29. }\end{array}$ https://doi.org/10.1016/j.biomed.2011.12.002 
[9] APHA. Compendium of Methods for the Microbial Examination of Foods. American public health association Washington DC, USA. 2001.

[10] ISO. International Organization for Standardization,. Microbiology of food and animal feeding stuffs-Horizontal methods for detection and enumeration of Enterobacteriaceae part2: colony-count technique. ISO (2004) Geneva, Switzerland.

[11] Pearson AM, Tauber FW. Deterioration of Processed Meat. Processed Meats: Springer Netherlands 1984;408-18. https://doi.org/10.1007/978-94-010-9692-8_18

[12] Yin M-c, Cheng W-s. Antioxidant and antimicrobial effects of four garlic-derived organosulfur compounds in ground beef. Meat Sci 2003;63:23-8. https://doi.org/10.1016/S0309-1740(02)00047-5

[13] Salem A. M., Amin R. A. and Afifi G. S. Studies on antimicrobial and antioxidant efficiency of some essential oils in minced beef. J Amer Sci 2010;6:691-700.

[14] Sallam KI, Ishioroshi M, Samejima K. Antioxidant and antimicrobial effects of garlic in chicken sausage. LWT - Food Sci Technol 2004;37:849-55. https://doi.org/10.1016/j.lwt.2004.04.001

[15] Javed MS, Khan MI, Randhawa MA, Sajid MW, Ahmad A, Khan MAN Garlic (Allium Sativum L.) as an antimicrobial and antioxidant agents in beef sausages. Pak J Food Sci 2011;21:22-32.

[16] Abd-Elghany SM. Improving quality of camel meat by garlic oil. Mansoura Vet Med J 2015;17

[17] Awan KA, Butt MS, UI-Haq I, Ashfaq F, Suleria HAR. Storage Stability of Garlic Fortified Chicken Bites. J Food Chem Nanotech 2017;03. https://doi.org/10.17756/jfcn.2017-041

[18] Wafy H, El-Bagory A-R, Shawish R. Antimicrobial activity of garlic and thyme essential oils against coliform bacteria in poultry meat. J Curr Vet Res 2019;1:11-8. https://doi.org/10.21608/jcvr.2019.56998 